\title{
THE STAKEHOLDERS ECOSYSTEM OF WAQF INSTITUTIONS IN MALAYSIA
}

\author{
Norman Hamdan ${ }^{1}$ \\ Ahmad Zamri Osman ${ }^{2}$ \\ Hafiz-Majdi Ab Rashid ${ }^{3}$
}

\begin{abstract}
Improved accounting and reporting practice for waqf institution in Malaysia has become an indispensable necessity. The identification of waqf stakeholders may help the institution to achieve this objective as the interest of these accounting users are to be properly addressed in the financial reports. This paper investigates the stakeholders of waqf and their relationship with waqf institution. Semi-structured interviews have been conducted involving 27 waqf managers and accountants from various organizations in waqf institution. Based on the thematic analysis, 18 groups of waqf stakeholders and three categories of stakeholder influential relationship have been identified. The results of this study provided a basis for waqf institution to further
\end{abstract}

1 Lecturer, Faculty of Economics and Muamalat, Universiti Sains Islam Malaysia, Bandar Baru Nilai, 71800, Negeri Sembilan, nhamdan@usim.edu.my

2 Assistant Professor, Kulliyyah of Economics and Management Sciences, International Islamic University Malaysia, P.O. Box 10, 50728 Gombak, Kuala Lumpur,azamrio@iium.edu.my

3 Associate Professor, Kulliyyah of Economics and Management Sciences, International Islamic University Malaysia, P.O. Box 10, 50728 Gombak, Kuala Lumpur, arhafiz@iium.edu.my 
determine which groups of waqf stakeholders that are salient in the efforts of providing the useful accounting information.

Keywords: waqf stakeholder, influential relationship, stakeholder ecosystem

\section{INTRODUCTION}

An organization shares a similar nature with individual human being, in that it exists in the inter- and intra-connected ecosystem. An action by one organization may impact or/and be impacted by other organizations' action. In other words, no organization is running its activities in silos. These other entities are commonly known as stakeholders to an organization. Managing or/ and engaging with these stakeholders has become one of the essential strategies undertaken by the management of an organization to ensure the achievement of its missions and objectives. This process of stakeholder engagement includes identifying the stakeholders and engaging the stakeholders. This paper focuses on the stakeholder identification and analysis processes whereby the identities of stakeholders of waqf institutions in Malaysia and their relationship are identified.

\section{LITERATURE REVIEW}

A stakeholder is defined by Freeman as "any group or individual who can affect or is affected by the achievement of an organization's objectives". ${ }^{4}$ Based on this definition, a stakeholder may be an individual or a group or an institution who are influenced by or exert an influence on the outcomes of an organization's decisions - directly or indirectly, for or against a change. Those who have "a stake" in an organization have something "at risk" due to their relationship with that organization. ${ }^{5}$ Therefore, if these constituencies perceived themselves as stakeholders of an organization, they believe that their interests are at risk as a result of decisions made by the organization. As such they will seek assurance to mitigate risks and/or to secure benefits from the organization to protect their interests. Nutt found that failure to attend the stakeholders' interests has been among the main factors for decision "failures" (i.e. they were not implemented at all, partially implemented or implemented but with poor results) of 50 percent of organizations' strategic decisions.

4 Freeman, R. Edward, Strategic Management: A Stakeholder Approach (Massachusetts: Library of Congress Cataloging in Publication Data, 1984).

5 Collier, Paul M., 'Stakeholder Accountability,' Accounting, Auditing \& Accountability Journal, vol. 21/7 (2008): 933-954. 
Hence, he proposed to get key stakeholders involved to ensure successful strategic decisions. ${ }^{6}$

Since Freeman introduced the idea of "stakeholder approach", the stakeholder theory has been embedded in the management and accounting studies for corporations and not-for-profit organizations (NPOs). ${ }^{7}$ The inclusion of any group or individual who can affect or be affected by the achievement of the organization's objectives in Freeman's definition of stakeholders have raised continuous debates on who are the stakeholders of the firm and to whom do managers pay attention to. Since then, identifying stakeholders is a real challenge for a firm and has become among the main discourses in numerous literature. Historically, organizations have always been said to emphasize the financial stakeholders - who are the funds providers, over other stakeholder constituencies. While attentions to these stockholders or funding agencies are inevitably still important to an organization, the organization is subject to the influence of a wider range of stakeholders. These stakeholders may have different "stakes" or claims towards the organizations based on the groups which they belong. Their expectation is to have their needs or interests well managed by the organizations. Failure to pay attention to these needs is an ingredient for organizational disaster. ${ }^{8}$ However, it may be impossible for an organization to completely satisfy all stakeholders at once, therefore, prioritizing is imperative. In doing so, an exercise of grouping stakeholders according to their interests should be first carried out before an organization starts analyzing their potential needs. Waqf as an entity also has its stakeholders to attend to.

Waqf is one type of charities in Islam. Unlike zakāh which is a compulsory charity, and sadaqah which is a voluntary charity, waqf is a perpetual charity. ${ }^{9}$ Collection and distribution of zakāh are well determined in Shariah, in term of the deserving recipients, the rate, the type of wealth and the (minimum) amount of wealth subject to zakāh. In other words, the condition for $z a k \bar{a} h$ is relatively specific. ${ }^{10}$ Șadaqah or voluntary charity, on the other hand, caters both Muslims and non-Muslims who are in need of some provisions and it is

$6 \quad$ Nutt, Paul C., 'Surprising but True : Half the Decisions in Organizations Fail,' Academy of Management Executive, vol. 13/4 (1999): 75-90.

7 Freeman, R. Edward, Strategic Management : A Stakeholder Approach.

8 Nutt, Paul C., 'Surprising but True : Half the Decisions in Organizations Fail,' 7590.

9 Sadeq, AbulHasan M., 'Waqf, Perpetual Charity and Poverty Alleviation,' International Journal of Social Economics, vol. 29/1\&2 (2002): 135-151.

10 Yusuf al-Qaradawi, Fiqh al-Zakah (Shah Alam: Islamic Book Trust, 2011). 
not bound by the specific conditions like zakāh. In other words, one can give sadaqah in any amount, at any time and to anybody who are in need of help. While sadaqah serves the society, it is a "one-off" giving. Normally when the recipients receive the donation, the benefit is immediately consumed and is not perpetual. Waqf offers a solution for the limitations that exist in both zakāh and șadaqah. Being a voluntary and perpetual form of charity, waqf serves everyone regardless of faith by providing continuous benefits that can be enjoyed intergenerationally. The word waqf is Arabic, which means to stop, contain or to preserve. It involves the perpetual preservation of property in order for it to continuously discharge its benefits for philanthropic purposes. Waqf is defined as the dedication of a property either in expressed terms or by implication, for any charitable or religious object, or to secure any benefit to human beings. ${ }^{11}$ Waqf - classified according to the purpose of its creation, is of two types; waqf am (general waqf) and waqf khas (specific waqf). ${ }^{12}$ Waqf am is defined as "any form of charitable dedication or endowment made to support all public welfare purposes without stating any special beneficiaries; be it any individuals, organizations or institutions", whereas waqf khas is "any form of dedication or endowment precisely declared for specific purposes or special beneficiaries". ${ }^{13}$

In waqf system, the donor (wāqif) contributes waqf asset (mawqūf) for specific or general purpose to be managed by a trustee (mutawallī). This trustee is then responsible to administer the waqf assets so that the assets could generate benefits that would be distributed to the beneficiaries (mawqūf 'alayh) as intended by wāqif. Traditionally the trustee is an individual appointed by wäqif to manage the waqf asset on his/her behalf. In the context of Malaysia, historically, the practice is that the waqf properties were assigned to respectable individuals within the community such as penghulu (heads of villagers), qadis (Islamic judge), religious teachers and mosque committees. This practice, however, was not well documented and hence eventually resulted in lots of waqf mismanagements. ${ }^{14}$ As the development of waqf system became more

11 Siti Mashitoh Mahamood, Waqf in Malaysia: Legal and Administrative Perspectives (Kuala Lumpur: Universiy Malaysia Press, 2006).

12 Ramli, Asharaf Mohd, Abdullaah Jalil, Suhaila Abdul Hamid \& Abdul Afuww Jalil, Wakaf IPT: Keperluan Insentif Cukai (Nilai: Wisdom Publication, 2017).

13 Ismail, Che Zuina, Nor Jana Salim \& Nor Jawanees Ahmad Hanafiah, 'Administration and Management of Waqf Land in Malaysia: Issues and Solutions,' Mediterranean Journal of Social Sciences, vol. 6/4 (2015): 613-620.

14 Siti Alawiah, Siraj, 'An Empirical Investigation into the Accounting, Accountability and Effectiveness of Waqf Management in the State Islamic Religious Councils (SIRCs) in Malaysia,' (Ph.D Thesis, Cardiff Business School, Cardiff University, UK, 2012). 
complex, the need for independent and specialized individuals or organizations to administer the waqf properties became apparent. The centralization of waqf management in Malaysia had started as early as 1938 when Council of Religion of Kelantan was appointed as sole trustee to monitor waqf assets in the state. ${ }^{15}$

Synthesizing the study of waqf and the understanding of stakeholder, the existence of waqf institution in the public sphere attracts the attention of and interest from its surrounding entities; i.e. the waqf stakeholders - individuals, groups or institutions. ${ }^{16}$ However, study of such focus is relatively scarce. In previous literatures, waqf stakeholders have been identified as donors, beneficiaries, government, public ${ }^{17}$, non-governmental organization waqf board ${ }^{18}$, waqf employee and regulator. ${ }^{19}$ However, these studies do not seem to embark into identifying waqf stakeholders - it is either presumed based on reading of literatures or/and based on the notion of stakeholders of similarnatured entity such as charitable organization. Such exercise tends to result in sidelining the "less important" waqf stakeholders. This current study identifies all possible stakeholders of waqf institutions in Malaysia through the qualitative interviews with the waqf managers and accountants.

\section{METHODOLOGY}

This study adopts a qualitative approach where data is gathered through semistructured interviews. A qualitative method of inquiry is deemed appropriate for this study because of its exploratory nature and lack of available secondary data on waqf financial reporting practices generally. This study explores waqf managers' perception on who are considered as waqf stakeholders. This

15 Siti Alawiah, Siraj, 'An Empirical Investigation into the Accounting, Accountability and Effectiveness of Waqf Management in the State Islamic Religious Councils (SIRCs) in Malaysia.'

16 Hoexter, Miriam, 'The Waqf and the Public Sphere,' in The Public Sphere in Muslim Societies (New York: State University of New York Press, 2002).

17 Ihsan, Hidayatul \& Adnan Muhammad Akhyar, 'Waqf Accounting and The Construction of Accountability,' Humanomics, vol. 27 (2011): 252-269.

18 Anna, Che Azmi \& Hanifa Mohamed Hisham, 'The Sharia-Compliance of Financial Reporting Practices: A Case Study on Waqf,' Journal of Islamic Accounting and Business Research, vol. 6/1 (2015): 55-72.

19 Ihsan, Hidayatul \& Shahul Hameed Hj. Mohamed Ibrahim, 'WAQF Accounting and Management in Indonesian WAQF Institutions: The Cases of Two WAQF Foundations,' Humanomics, vol. 27/4 (2011): 252-269. 
perceptual information is best captured through interviews as the researcher could observe the views of interviewees on the subject matter that are expressed verbally as well as non-verbally. ${ }^{20}$ In this study semi-structured interviews are primarily used as the means for data collection. The purpose of interviewing is to get other people's perspective and how they render meaning on events of interest to researchers. ${ }^{21}$ This process, as O'Dwyer refers as "the process of getting inside their head" ${ }^{22}$ offers a greater understanding on why the financial reporting is being practiced in waqf institution and how the salient nature of waqf stakeholders influence the reporting practice. A total of 27 interviewees were involved consist of waqf managers, accountants and academician from State Islamic Religious Councils (SIRCs), public universities, waqf corporations, and corporate entities.

\section{RESEARCH FINDINGS}

Running as an organization that uphold both social and economic missions, waqf institutions may have different groups of stakeholders relative to other organizations. The identification of waqf stakeholders is essential as this may influence the financial reporting practice because they are the users of such reports. Proper reporting implies that organization provides useful information to meet the information needs of the users. Such information should be timely, accurate, relevant and reliable in nature so as to assist the users in their decision-making processes. ${ }^{23}$ In order to understand the nature of information needed in the reports, the organization should first identify the users of their report; hence their stakeholders.

\section{Identity of Waqf Stakeholders}

The question of "who are the stakeholders of this institution" was asked to each interviewee during the semi-structured interview sessions. Various responses

20 Alsaawi, Ali, 'A Critical Review of Qualitative Interviews,' European Journal of Business and Social Sciences, vol. 3/4 (2014): 149-156.

21 O'Dwyer, Brendan, 'Qualitative Data Analysis: Illuminating a Process for Transforming a 'Messy ' but 'Attractive' 'Nuisance', in Real Life Guid. to Account. Res. A behind-the-Scenes View Using Qual. Res. Methods, vol. 5, ed. C. Humphrey (Oxford, UK: Elsevier, Ltd., 2004), 391-408.

22 O'Dwyer, Brendan, 'Qualitative Data Analysis: Illuminating a Process for Transforming a 'Messy ' but 'Attractive' 'Nuisance', 391-408.

23 Hall, James A., Accounting Information System, ed. James A. Hall (Singapore: Cengage Learnin, 2016). 
were received from the interviewees on the identity of waqf stakeholders and some of them were similar. The following are examples of their responses and their views on who the stakeholders are;

"When we talk about waqf, Allah SWT is the most important stakeholder. He is the ultimate stakeholder because according to Shariah, we relinquish our ownership of the asset to Him." (Chairman, Waqf-M).

This shows that the ultimate stakeholder of waqf institution is Allah; the God Almighty. In the concept of waqf, once assets are donated for waqf purposes, their ownership belongs to Allah. ${ }^{24}$ Being the ultimate owner of waqf assets, Allah is viewed as the most important stakeholder that the institution should be concerned with. There were also other responses as highlighted below,

"Wāqif is the stakeholder of waqf. They consist of various individuals including the students, staffs, alumni, and subsidiary companies." (Head of Waqf Division, Waqf-K).

Waqf contributor is known as wāqif. They are among the important stakeholders in waqf as they are one of the pillars of waqf. They have the authority to decide the purposes of the waqf assets that they contributed. Another group of stakeholders is beneficiaries, as follows;

"Beneficiary is a pillar of waqf. Beneficiary can be the one who receive the right to use the waqf property or the one who receive the benefit of waqf property. It has to exist, otherwise the waqf is nullified." (Head of Waqf Division, Waqf-G).

The beneficiary is the receiving end of waqf benefits. They are the receivers of waqf benefits whom the wāqif has stipulated specifically or generally upon contributing the waqf assets. As mentioned by the interviewee in Waqf-G, the beneficiary could have the right to use the waqf property. An example of this is the tenant who rent waqf house or shop lot. The other type of beneficiary is the one who receive the benefits from the rentals of such waqf properties. The benefits could be in the form of cash from the rentals or other non-monetary assistance or supports from the waqf.

"Special waqf is bound by Shariah. Every single matter we have to report to fatwa meeting. That's why for the distribution

24 Kahf, Monzer, 'Towards the Revival of Awqaf: A Few Fiqhi Issues to Reconsider,' (Paper presented, Harvard Forum Islam, Financial and Economics, Harvard University, USA, 1 October 1999). 
we have to ask the approval from fatwa committee before being distributed." (Waqf Assistant Officer, Waqf-C).

The above indicates managers/management as one of the stakeholders. The management of waqf properties is bound by Shariah requirement especially for waqf khas (special waqf) whereby the wäqif has specified the purpose of such waqf. Any issues related to such waqf should be brought to the attention of fatwa committee who will decide the best possible Shariah-based solutions. There is also a lesser-discussed waqf stakeholder - per literatures, such as banking institution.

"Bank Islam provides financing to the SIRCs to develop waqf properties. They all play their roles... all have interest [on waqf]" (Executive Officer, Waqf-I).

In this study the entities such as banking institutions which provides financial assistance in the development of waqf projects and properties are categorized as waqf partners. Their willingness in financing the waqf projects helps in overcoming the problems of undeveloped or under-developed waqf lands and properties. With their limited financial capability, SIRCs - as the waqf mutawalli, finds it very challenging to develop waqf properties without assistance from these waqf partners. Meanwhile, the stakeholder from public sector is also identified.

\section{"There is an effort between the National Accounting Department and universities' researchers to develop accounting standard but not only for waqf. It includes waqf, zakāh and Baitul mal." (Finance Manager, Waqf-A).}

As the regulator of accounting practices, the role of the National Accounting Department is essential in the development of waqf especially in their effort to introduce some guidance/standard on reporting practices for waqf activities. There are also waqf partners.

"The council establishes and appoints Pusat Wakaf Sdn Bhd as its agent to collect waqf funds." (Finance Manager, Waqf-D).

Waqf agent (al Qayyim) is another type of waqf stakeholder. It could be an individual or an organization appointed by the mutawalli with a duty to collect waqf funds or assets from the public. The study also identifies researcher as one of the stakeholders.

"The research (on waqf) by the researchers. This is another (stakeholder) that plays an important role in waqf institution" (Executive Officer, Waqf-I). 
Their roles in investigating waqf issues and providing some recommendation for waqf-related problems is seen by the officer as improving and strengthening the institution of waqf in Malaysia.

The above are examples of waqf stakeholders that have been identified through interviews with waqf managers. The study's thematic analysis has identified at least eighteen groups of stakeholders of waqf institutions in Malaysia. The interviewees have also identified the stakes/interest of each waqf stakeholder on the waqf institutions. The idea of stake is important in order to appreciate the concept of stakeholder as stake "can range from simply an interest in an undertaking at one extreme to a legal claim of ownership at the other extreme". ${ }^{25}$ A person or group is considered to have an interest in a particular decision when the person/group is affected by the decision. Table 1 summarizes the list of eighteen stakeholders of waqf and their respective stakes/rights/claims.

Table 1: Waqf Stakeholders and Their Stakes

\begin{tabular}{|c|c|c|}
\hline & Stakeholder & The Stakes/claims/interest \\
\hline 1. & Allah & $\begin{array}{l}\text { Waqf assets being managed according to rules and } \\
\text { laws of Shariah. }\end{array}$ \\
\hline 2. & Wāqif & The $w a q f$ purpose is successfully fulfilled. \\
\hline 3. & Beneficiaries & The benefits they are entitled for. \\
\hline 4. & Sultan & $\begin{array}{l}\text { The right to be advised on matters relating to } \\
\text { Islamic affairs and to appoint certain members of } \\
\text { the councils. }\end{array}$ \\
\hline 5. & $\begin{array}{l}\text { State Islamic } \\
\text { Religious } \\
\text { Councils } \\
\text { (SIRCs) }\end{array}$ & $\begin{array}{l}\text { The trust in carrying out the purpose of waqf as } \\
\text { stipulated in waqf deeds. }\end{array}$ \\
\hline 6. & Nazir khas & $\begin{array}{l}\text { The trust in carrying out the purpose of waqf as } \\
\text { stipulated in waqf deeds (representative of SIRC). }\end{array}$ \\
\hline & Agent & $\begin{array}{l}\text { The trust in promoting waqf and collecting waqf } \\
\text { funds from the public. }\end{array}$ \\
\hline
\end{tabular}

25 Buchholtz, Ann K \& Archie B Carroll, Business \& Society: Ethics \& Stakeholder Management, 7th ed. (Ohio: South-Western Cengage Learning, 2009). 


\begin{tabular}{lll}
\hline \multicolumn{1}{c}{ Stakeholder } & \multicolumn{1}{c}{ The Stakes/claims/interest } \\
\hline 8. Board members & $\begin{array}{l}\text { The authority to make strategic decisions in waqf } \\
\text { institution. }\end{array}$ \\
9. Fatwa committee & $\begin{array}{l}\text { The authority to make decisions on shariah-related } \\
\text { issues. } \\
\text { Opinions on the waqf institutions' compliance } \\
\text { with the reporting requirements. } \\
\text { 10. Auditors }\end{array}$ & $\begin{array}{l}\text { Right to vote and information access. } \\
\text { The cooperation between the SIRCs and other external } \\
\text { parties. }\end{array}$ \\
11. Members & $\begin{array}{l}\text { That all projects undertaken are developed based on } \\
\text { 12. Sules and regulation. }\end{array}$ \\
13. Gocial & Committee & Cooperation in developing waqf properties. \\
14. Waqf partners & The compliance of waqf institutions to the regulations. \\
15. Regulators & The right to use waqf assets or properties. \\
16. Consumers & The right to information of waqf. \\
17. Public & Their interest in exploring waqf related issues. \\
18. Academician &
\end{tabular}

Source: Own interview data

\section{DISCUSSIONS AND RECOMMENDATIONS}

Some of the stakeholders share similar rights. The finding shows the complexity of waqf institutions operating in the highly interconnected environment. This waqf stakeholder ecosystem which involves a group of interconnected elements, formed by the interaction of a community of individuals and organizations with their environment, is clearly in need of a language that can describe the relationship and the role. In a biological ecology, the interrelationships between the organisms that can range from symbiotes to parasites, from predator to prey, the roles and relationships are much more clearly defined. This metaphor can assist us in better understanding the waqf stakeholder relationships and their influence on waqf institutions. By developing the connection/s between and among the stakeholders and having a better description of the nature of the stake being held or claimed, we can understand the ecosystem better. This paper suggests one way of understanding the ecosystem - the relationship 
among waqf stakeholders by looking at the notion of affecting or/and affected relationship.

\section{UNDERSTANDINGDIVINESTAKEHOLDER IN WAQFINSTITUTION}

Before proceeding with the discussion on the notion of affecting or/and affected relationship of waqf stakeholders, it is important to understand the issue relating to divine stakeholder in organizational setting. One of the waqf stakeholders that have been identified in this study is Allah; the God All Mighty. All interviewees refer Allah as the ultimate stakeholder of waqf institution. Several issues may arise on having Allah as the stakeholder of an organization. Can or should Allah be a stakeholder of an organization? This prominent question could be addressed through two perspectives; the Shariah viewpoint on the ownership of waqf properties and the descriptive definition of stakeholder.

According to Freeman, the owner of an entity should always be a stakeholder because the interest of the owner is the principle stake in the ecosystem of stakeholders. ${ }^{26}$ It is the need of every business owner, for example, to have his/her business is run by the managers in effective and efficient manner so as to achieve his/her business goals and objectives i.e.; his/her ultimate interest. In waqf context, the waqf assets being managed by the mutawalli do also have their owner(s). From the Shariah viewpoints, the Muslim scholars differ in their views on who is (are) the owner(s) of waqf assets once they are entrusted to the mutawallī. There are at least two different opinions among Muslim scholars on this waqf ownership issues. First, waqf assets remain on the ownership of the founder which is wäqif. This is the view of Abu Hanifah and Mālik. ${ }^{27}$ Wãqif can continue own the assets and can also revoke the waqf at any time. Second, waqf assets are impliedly owned by Allah once they are dedicated as waqf. This opinion is shared by majority of Muslim scholars including Shāfi‘'̄, Aḥmad Ibn Hanbal and two disciples of Abū Hanīfah; Abū Yūsuf and Muhammad al-Shaybanī ${ }^{28}$ The ownership of founder on the waqf assets extinguishes and transferred to Allah. Based on second view of Muslim scholars on the ownership of waqf assets, Allah, as the ultimate owner of waqf assets may become the stakeholder of waqf institutions. This second view is

26 Freeman, R. Edward, Strategic Management : A Stakeholder Approach.

27 Abbasi, Muhammad Zubair, 'The Classical Islamic Law of Waqf: A Concise Introduction,' Arab Law Quarterly, vol. 26 (2012): 121-153.

28 Abbasi, Muhammad Zubair, 'The Classical Islamic Law of Waqf: A Concise Introduction,' 121-153. 
endorsed by the Muslims in Malaysia as they officially subscribe to Shāfi ‘ $\overline{1}$ school of thought pertaining to the Shariah issues. One interviewee said; "all waqf assets belong to Allah, and in this case we (waqf corporation) are responsible as a trustee (Deputy CEO, Waqf-J)". On this note, in managing waqf assets the waqf managers are ultimately accountable to Allah, as the owner of waqf assets.

The second perspective to address the question on the issue of divine stakeholder is by understanding the definition of stakeholder. Building on Freeman's definition of stakeholder as "any group or individual who can affect or is affected by the achievement of the organization's objectives" 29 and his normative principle of "who or what really counts", it may be possible to regard Allah as a "stakeholder" for an "organization". As the ultimate owner of not only waqf assets but all that exist in this world, man has to abide by the laws and rules of Allah. One interviewee elaborated on this when he said; "we have to protect the rights of Allah in terms of the laws that He has stated (Chairman, Waqf-N)". This is how Allah, as the Almighty God can affect the organization on doing something in accordance to the will of Allah. Schwartz agrees that God should be considered a managerial stakeholder and this suggestion is only relevant to those who believe in a supreme entity. ${ }^{31}$ Waqf institutions is Islamic organizations and managed by Muslim managers. Their belief in the Omnipotence of Allah is the reason for these waqf managers to consider Allah as the ultimate stakeholder of waqf institutions.

Having said that Allah may become a stakeholder of an organization does not mean that Allah can be equated with other human and non-human stakeholders in the sense of equality in attributes. Allah has clearly said in the Qur'ān;

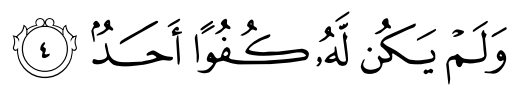

"Nor is there to Him any equivalent.."

(Surah al-Ikhlāṣ, 112: 4)

Allah should be considered as special stakeholder that possess all Perfect Attributes. Therefore, in the Figure 1, the position of Allah is placed above other groups of waqf stakeholders. Apart from having influential connection

\footnotetext{
29 Freeman, R. Edward, Strategic Management : A Stakeholder Approach, 46.

30 Freeman, R. Edward, 'The Politics of Stakeholder Theory: Some Future Directions,' Business Ethics Quarterly, vol. 4/4 (1994): 409-421.

31 Schwartz, Mark S., 'God as a Managerial Stakeholder?' Journal of Business Ethics, vol. 66 (2006): 291-306.
} 
(represented by the arrows) with waqf institutions (SIRCs and nazir khas), Allah can also influence other groups of waqf stakeholders as well (represented by arrow connecting to dotted box enclosing the stakeholders). Waqf institutions (SIRCs and nazir khas) are clearly accountable to Allah (the owner of waqf assets) because they are the entities that directly manage the waqf assets. Other stakeholders (wāqif, beneficiaries, sultan, agent, board members, fatwa committee, auditors, members, special management committee, government, waqf partners, regulators, consumers, public and academician) that are parts of this waqf ecosystem are also accountable to Allah for their actions that may relate indirectly to waqf assets.

The following discussion focuses on the accountability relationship of waqf institutions (SIRCs and nazir khas) as the entities that manage the waqf assets with other groups of waqf stakeholders. In this waqf ecosystem, SIRCs and nazir khas are the mutawalli of waqf and the reporting entities.

\section{POWER-DEPENDENCE RELATIONSHIP ANALYSIS}

Freeman characterizes stakeholders as "any group or individual who can affect or is affected by the achievement of an organization's objectives". ${ }^{32}$ Adopting this notion of affecting or/and affected relationship, this study classifies the stakeholders of waqf institutions into three categories of influential relationship; power-dependence (stakeholder dominant), power-dependence (firm dominant) and mutual power-dependence. ${ }^{33}$ The diagram in Figure 1 depicts the relationship of waqf stakeholders.

Power-dependence relationship is a situation whereby one entity gives effect to another entity unidirectionally - either entity A affects entity B or vice versa. Therefore, there are two forms of single direction of power-dependence relationship; (i) Power-dependence (stakeholder dominant) - individual or group whose operation can influence but not dependent on the firm's activities; and (ii) Power-dependence (firm dominant) - individual or group who cannot influence but dependent on the firm's activities. Meanwhile, mutual powerdependence relationship is a situation whereby the reciprocal effect exists between two entities. Entity A affects; and is also affected by entity B.

In this power-dependence relationship, the SIRCs and nazir khas represent waqf institutions themselves in this study. The SIRCs consist of eight State

32 Freeman, R. Edward, Strategic Management : A Stakeholder Approach, 46.

33 Williams, Paul F. \& Sue P. Ravenscroft, 'Rethinking Decision Usefulness,' Contemporary Accounting Research, vol. 32/2 (2015): 763-788. 
Islamic Religious Councils under study and nazir khas represents waqf corporations, waqf managing universities and waqf managing companies. When asked who their stakeholders are, the managers in the SIRCs replied, among others, the nazir khas are their stakeholders as they are appointed by the SIRCs to manage waqf assets on the SIRCs' behalf. One of the participants from the SIRCs replied; "the waqf corporation acts as administrator of waqf. In terms of responsibility, power, it is still under the SIRC's jurisdiction. (Accountant, Waqf-J)". Likewise, when the same question was asked to managers in waqf institutions represented as nazir khas, they regard the SIRCs as their main stakeholders. One participant from nazir khas category replied; "whatever decision made by the SIRC, we have to follow. We execute all the instructions that come from the SIRC from time to time (Deputy CEO, Waqf-J)".

Both SIRCs and nazir khas are the focal point of this study whose achievements in managing waqf are affected by some waqf stakeholders and can affect other waqf stakeholders as well. As for other stakeholder groups, each fall into one of three classifications of stakeholder characteristics as stated in Table 2. The classifications include (i) power-dependence (stakeholder dominant): influencing but not dependent, (ii) power-dependence (firm dominant): not influencing but dependent, and (iii) mutual power-dependence: influencing and dependent on each other. Figure 1 shows the relationship among these waqf stakeholders. The arrows indicate the influence of one entity on the other.

\section{Stakeholder Dominant: Influencing but Not Dependent}

The first classification of stakeholder groups is those that may affect the dayto-day activities of waqf institutions. The decisions and activities made by this group of stakeholders with regard to waqf influences directly or indirectly the decisions and activities of waqf institutions. These stakeholders, however, are not susceptible to the institutions' activities. The stakeholders in this category are Allah, sultan, fatwa committee, highest management officials, government, regulators, auditors, waqf partners, and academician. For example, Allah is the highest authority and His Law controls the way the waqf institutions operate, especially in terms of the principle of waqf that the institutions must follow, including any Shariah provisions derived from Qur 'ān and prophetic tradition. One interviewee said: "We have to protect the rights of Allah, that is, in terms of the laws (Shariah) that He has enforced on us (Chairman, Waqf-N)". All waqf activities must be conducted in accordance with the Shariah requirements. Waqf institutions, however, have no ability to affect Allah in anyway. In other words, as the stakeholder of waqf, Allah Himself is not affected by any decisions and actions made by waqf institutions. 
The audit opinions from the auditors may also result in waqf institutions improving their operational activities. However, the auditors themselves may not be affected by the noncompliant activities of waqf institutions. One of the interviewees said; "Since 2 to 3 years ago, we have already taken the appropriate actions because we received audit warning in 2013 (Accountant, Waqf-G)". Prior to receiving caution from auditor, Waqf-G had never officially informed the beneficiaries regarding the accumulated benefits for which they are entitled. Waqf-G has since started producing individual reports for each group of waqf beneficiary. Whether or not Waqf-G complies with the recommendation in the audit warning does not affect the auditor.

The academicians undertaking waqf-related research is another stakeholder belong to this group. They may produce academic research/papers/reports concerning waqf issues. The issues and their possible solutions highlighted by these academicians in the papers may or may not be used by waqf institutions in enhancing the management of waqf. This role of academicians is recognized by an interviewee when he said, "all the research done by the lecturers, play an important role in this institution (Accountant, Waqf-I)". The academicians have no "direct" relationship with waqf institutions. Any response shown by the institutions upon receiving the research report may not give any impact on their academic works.

\section{Firm Dominant: Not Influencing but Dependent}

The second classification is those groups whose actions do not give any effect on the operations of waqf institutions, but they are affected by the decisions and actions of the institutions. Special management committee, consumers, agent, public and beneficiaries are stakeholder sharing this stakeholder characteristic. The public may indirectly receive benefits from waqf development if the waqf is created for general purposes. But it may not be possible for the public to influence the operations of waqf institutions as they are largely considered to be at the receiving end of waqf services. Meanwhile, with regards to special management committee, an interviewee said; "we have one division that handle waqf in this state and this division in under the jurisdiction of the SIRC (Accountant, Waqf-I)". These management committee are formed to execute the waqf projects as planned by the SIRC. Therefore, its existence is dependent upon SIRC's decision and by this virtue they do not - to a great extent - have the power to influence SIRC. 
Figure 1: Waqf Stakeholders: Power-dependence Relationship

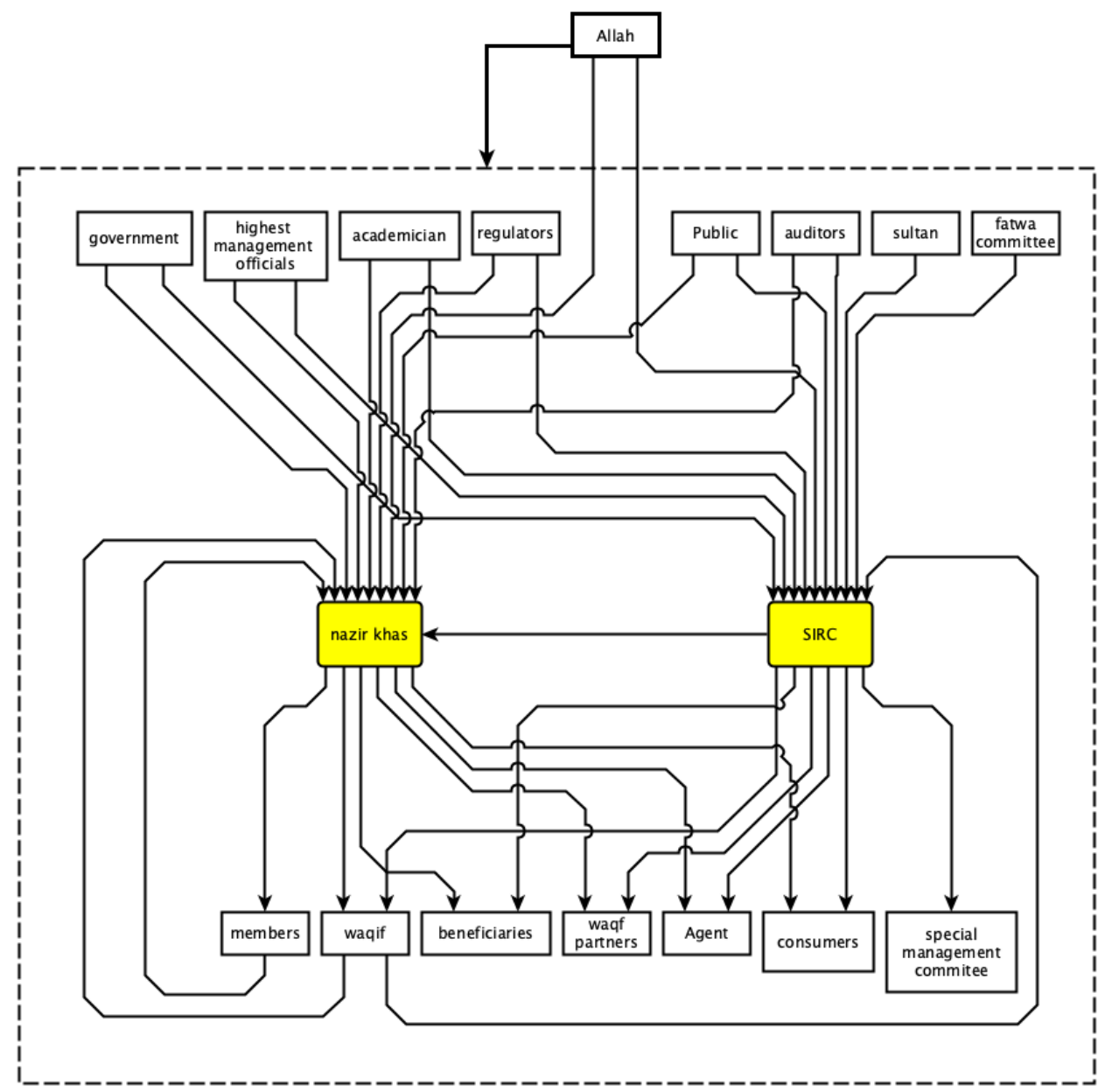

Source: Own construction based on interview data

Another example is the beneficiaries who are dependent on the SIRC for the waqf benefits they are entitled. One interviewee explained "we will give the benefits from waqf to the beneficiaries if profits could be generated from these waqf lands (Deputy CEO, Waqf-J)". This shows that, the beneficiaries do not seem to have the ability to influence waqf institutions, but they are clearly affected by the activities of the institutions with regards to the distribution of waqf benefits of which they are entitled to. 
Table 2: Influential Characteristics of Waqf Stakeholders

\begin{tabular}{lll}
\hline \multicolumn{1}{c}{\begin{tabular}{c}
\multicolumn{1}{c}{$\begin{array}{c}\text { Relationship } \\
\text { Categories }\end{array}$} \\
Power-dependence \\
(Stakeholder \\
Dominant)
\end{tabular}} & $\begin{array}{l}\text { Chfluencing but not } \\
\text { dependent }\end{array}$ & $\begin{array}{l}\text { Allah, sultan, fatwa committee, } \\
\text { highest management officials, } \\
\text { government, regulators, auditors, } \\
\text { waqf partners, academician. }\end{array}$ \\
$\begin{array}{l}\text { Power-dependence } \\
\text { (Firm Dominant) }\end{array}$ & $\begin{array}{l}\text { Not influencing but } \\
\text { dependent }\end{array}$ & $\begin{array}{l}\text { Special management committee, } \\
\text { consumers, agent, beneficiaries, } \\
\text { public. }\end{array}$ \\
$\begin{array}{l}\text { Mutual Power- } \\
\text { dependence }\end{array}$ & $\begin{array}{l}\text { Influencing and } \\
\text { dependent }\end{array}$ & \begin{tabular}{l} 
SIRCs, nazir khas, wāqif, members. \\
\hline
\end{tabular} \\
\hline
\end{tabular}

Source: Own construction based on Williams, Paul F. and Sue P. Ravenscroft ${ }^{34}$

\section{Mutual Power-dependence: Influencing and Dependent}

The third classification is those groups whose decisions and actions may both affect and be affected by the operational activities of waqf institutions. In other words, there is a reciprocal influence between them and the institutions. SIRCs, nazir khas, wāqif, public, and members belong to this group of waqf stakeholders. The actions, decisions or activities of these stakeholders may affect waqf institution's operation and at the same time their daily operations may be affected by the actions, decisions or activities of waqf institutions.

For example, when waqf institutions manage the waqf assets properly and distribute waqf benefits accordingly, the intention of wāqif is successfully fulfilled, and the wäqif may receive perpetual reward from Allah. One waqf manager explained, "...the perpetual reward (jāriyah) starts when the waqf assets being developed/used (Deputy CEO, Waqf-J)". Therefore, it is important that waqf properties are properly developed and utilized to ensure the continuous reward for wäqif. At the same time, the sustainability of waqf institutions is mostly dependent on the continuous contribution from the waquif or other potential wāqif. The statement by a waqf manager, "the wäqif is the driven force of this institution, because they are the ones who contribute (waqf assets) (General Manager, Waqf-B)", shows how important wāqif is to the

34 Williams, Paul F. \& Sue P. Ravenscroft, 'Rethinking Decision Usefulness,' Contemporary Accounting Research, vol. 32/2 (2015): 763-788. 
waqf institutions. The contribution of assets by these wäqifs for waqf purposes is the real reason for the existence of waqf institution. This institution exists because it is entrusted to manage the waqf assets contributed by wäqif.

\section{CONCLUSION}

Proper identification and analysis of stakeholders are important for waqf institution as these exercises may help the institution to better engage with their stakeholders. ${ }^{35}$ Knowing who are stakeholders would assist a firm in responding better to their respective interests or stakes that they may have on the firm. Stakeholder engagement is an important ingredient to ensure the sustainability of the institutions. ${ }^{36} \mathrm{~A}$ total of eighteen stakeholders of waqf institutions has been identified in this study. This finding shows that the operation of waqf institution in managing waqf assets does attract the attention from various individual and organizational stakeholders. The ecosystem where waqf institution operates in involves complex interactions among these stakeholders. Further analysis on the stakeholder relationship resulted in three classifications of waqf stakeholders based on the notion of power-dependence relationship. Nine waqf stakeholder groups are classified under power-dependence (stakeholder dominant) relationship. These groups of stakeholders seemed to have influence but are not dependent on waqf institution. Five groups of waqf stakeholders are classified under powerdependence (firm dominant) relationship. In this category, the stakeholders do not have any influence on waqf institution, but they are dependent or affected by the decisions and actions of the institution. The remaining four groups of waqf institution are classified under mutual power-dependence relationship. The (in)decisions and (in)actions of these waqf stakeholder groups may affect the operational activities of waqf institutions and at the same time they can be affected by the institutions' activities. This typology of waqf stakeholder paves the ways for future researches in various areas. Different classes of waqf stakeholders may require different engagement strategy by waqf institutions. It is hoped that a better stakeholder engagement strategy could be developed by waqf institution based on this waqf stakeholder typology ecosystem to ensure the sustainability of the institutions.

35 Neville, Benjamin A., Simon J. Bell \& Gregory J. Whitwell, 'Stakeholder Salience Revisited: Refining, Redefining, and Refueling an Underdeveloped Conceptual Tool,' Journal of Business Ethics, vol. 102/3 (2011): 357-378.

36 Donaldson, Thomas \& Lee Preston, 'Theory the Stakeholder of the Concepts, Evidence, Corporation and Implications,' Management, vol. 20/1 (1995): 65-91. 


\section{REFERENCES}

Abbasi, Muhammad Zubair, 'The Classical Islamic Law of Waqf: A Concise Introduction,' Arab Law Quarterly, vol. 26 (2012): 121-153.

Abu Zahrah, Muhammad, WakafMenurut Agama \& Undang-Undang, ed. H.M. Yusuf Sinaga, Mohd Sofwan Amrullah, Nor Mawaddah Awwaluddin \& Ramzilah Ramlan (Selangor: Jasmin Enterprise, 2007).

Alsaawi, Ali, 'A Critical Review of Qualitative Interviews,' European Journal of Business and Social Sciences, vol. 3/4 (2014): 149-156.

Anna, Che Azmi \& Hanifa Mohamed Hisham, 'The Sharia-Compliance of Financial Reporting Practices: A Case Study on Waqf,' Journal of Islamic Accounting and Business Research, vol. 6/1 (2015): 55-72.

Buchholtz, Ann K \& Archie B Carroll, Business \& Society: Ethics \& Stakeholder Management, 7th ed. (Ohio: South-Western Cengage Learning, 2009).

Collier, Paul M., 'Stakeholder Accountability', Accounting, Auditing \& Accountability Journal, vol. 21/7 (2008): 933-954.

Donaldson, Thomas \& Lee Preston, 'Theory the Stakeholder of the Concepts, Evidence, Corporation and Implications,' Management, vol. 20/1 (1995): 65-91.

Freeman, R. Edward, 'The Politics of Stakeholder Theory: Some Future Directions,' Business Ethics Quarterly, vol. 4/4 (1994): 409-421.

Freeman, R. Edward, Strategic Management: A Stakeholder Approach (Massachusetts: Library of Congress Cataloging in Publication Data, 1984).

Hall, James A., Accounting Information System, ed. James A. Hall (Singapore: Cengage Learnin, 2016).

Hoexter, Miriam, 'The Waqf and the Public Sphere', in The Public Sphere in Muslim Societies (New York: State University of New York Press, 2002).

Ihsan, Hidayatul \& Adnan Muhammad Akhyar, 'Waqf Accounting and The Construction of Accountability,' Humanomics, vol. 27 (2011): 252-269.

Ihsan, Hidayatul \& Shahul Hameed Hj. Mohamed Ibrahim, 'WAQF Accounting and Management in Indonesian WAQF Institutions: The Cases of Two WAQF Foundations,' Humanomics, vol. $27 / 4$ (2011): 252-269.

Ismail, Che Zuina, Nor Jana Salim \& Nor Jawanees Ahmad Hanafiah, 'Administration and Management of Waqf Land in Malaysia: Issues and Solutions,' Mediterranean Journal of Social Sciences, vol. 6/4 (2015): 613-620. 
Kahf, Monzer, 'Towards the Revival of Awqaf: A Few Fiqhi Issues to Reconsider,' (Paper presented, Harvard Forum Islam, Financial and Economics, Harvard University, USA, 1 October 1999).

Neville, Benjamin A., Simon J. Bell \& Gregory J. Whitwell, 'Stakeholder Salience Revisited: Refining, Redefining, and Refueling an Underdeveloped Conceptual Tool,' Journal of Business Ethics, vol. 102/3 (2011): 357-378.

Nutt, Paul C., 'Surprising but True : Half the Decisions in Organizations Fail,' Academy of Management Executive, vol. 13/4 (1999): 75-90.

O’Dwyer, Brendan, 'Qualitative Data Analysis: Illuminating a Process for Transforming a 'Messy ' but 'Attractive' 'Nuisance', in Real Life Guid. to Account. Res. A behind-the-Scenes View Using Qual. Res. Methods, vol. 5, ed. C. Humphrey (Oxford, UK: Elsevier, Ltd., 2004), 391-408.

Ramli, Asharaf Mohd, Abdullaah Jalil, Suhaila Abdul Hamid \& Abdul Afuww Jalil, Wakaf IPT: Keperluan Insentif Cukai (Nilai: Wisdom Publication, 2017).

Sadeq, AbulHasan M., 'Waqf, Perpetual Charity and Poverty Alleviation,' International Journal of Social Economics, vol. 29/1\&2 (2002): 135151.

Schwartz, Mark S., 'God as a Managerial Stakeholder?' Journal of Business Ethics, vol. 66 (2006): 291-306.

Siti Alawiah, Siraj, 'An Empirical Investigation into the Accounting, Accountability and Effectiveness of Waqf Management in the State Islamic Religious Councils (SIRCs) in Malaysia,' (Ph.D Thesis, Cardiff Business School, Cardiff University, UK, 2012).

Siti Mashitoh Mahamood, Waqf in Malaysia: Legal and Administrative Perspectives (Kuala Lumpur: Universiy Malaysia Press, 2006).

Williams, Paul F. \& Sue P. Ravenscroft, 'Rethinking Decision Usefulness,' Contemporary Accounting Research, vol. 32/2 (2015): 763-788.

Yusuf al-Qaradawi, Fiqh al-Zakah (Shah Alam: Islamic Book Trust, 2011). 